International Journal of Instruction e-ISSN: 1308-1470 • www.e-iji.net

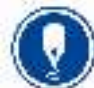

July $2021 \bullet$ Vol. 14, No. 3
p-ISSN: $1694-609 X$
pp. 255-270

Article submission code: 20200710161356

Received: 10/07/2020

Revision: 11/12/2020
Accepted: 04/01/2021

OnlineFirst: 06/05/2021

\title{
Dialogic Literary Circles as a Methodological Strategy for the training of students in Early Childhood Education Degree
}

\section{Estefanía Martínez-Valdivia}

Corresponding autor, University of Jaén, Spain,evaldivi@ujaen.es

$M^{a}$ Carmen Pegalajar-Palomino

University of Jaén, Spain, mcpegala@ujaen.es

\section{Lina Higueras-Rodríguez}

University of Almería, Spain, mlinahr@ual.es

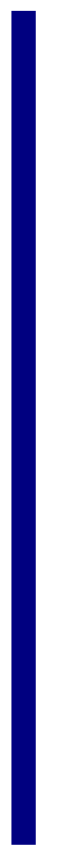

The research has the purpose of analyzing the experience of the students of the first course of the Early Childhood Education Degree on the methodology of the Dialogic Literary Circles. The aim is to examine the variables that influence the academic performance of the future teacher, as well as the conditions that have an impact on their teaching-learning process, including Dialogical Literary Circles. A qualitative methodology has been used, from a phenomenological perspective. The Dialogic Literary Circles were implemented in the subject of "General Didactics" in the Early Childhood Education Degree during the year 2019-2010. The study is aimed at 230 students, of which 90 of them have agreed to participate in the discussion groups (9 groups of 10 people each) to collect the data. A script has been developed to direct the students' discourse and find out their perception of this methodological strategy. A content analysis was carried out with the information obtained, helping us from the Nvivo 12 program. Were obtained very positive results on the implications of this methodological strategy for the training of the university student. The students consider that through the Dialogic Literary Circles they have acquired pedagogical knowledge, but also this strategy has led them to value the collaborative work, the respect for the opinions of their peers, has encouraged reading and expanded vocabulary, besides developing communication and oral expression skills. Therefore, conclude that it is an active methodology, very pertinent to put it into practice at university, since it encourages in the initial training of teachers to be professionals with the skills required in today's society.

Keywords: initial training, teacher, active methodology, dialogic learning, sustainable education, training

Citation: Martínez-Valdivia, E., Pegalajar-Palomino, Mª C., \& Higueras-Rodríguez, M. L. (2021). Dialogic literary circles as a methodological strategy for the training of students in early childhood education degree. International Journal of Instruction, 14(3), 255-270. https://doi.org/10.29333/iji.2021.14315a 


\section{INTRODUCTION}

Higher Education is committed to a new pedagogical model to offer a quality education for all students and to train professionals with sufficient skills to respond to the demands of our society. University must assume new socio-educational needs in which the student plays an active, participative and social role; the levels of interaction between teacher-student, student-student and content are increased, as well as dialogue and interaction, and the development of the teaching process (Soler et al., 2020). In addition, the acquisition of skills and abilities that prepare the student for their future professional activity and improve their employability should be facilitated (Martín et al., 2020).

As a result of the European convergence process, some of the assumptions underlying the conception of the teaching-learning process have been transformed (Zabalza, 2016), based on the active and responsible role of the student (Vallet-Bellmunt et al., 2017). This methodological change generates an increase in student motivation towards learning, while favouring peer interaction and their level of commitment to study (Mingorance et al., 2019).

In this context, it is important to highlight the Dialogic Literary Circles understood as one of the Successful Educational Actions developed as a result of the European research project INCLUD-ED (Arrow, 2015). This didactic tool is based on the concept of dialogical learning, guided by principles based on equality and difference as compatible and enriching values for all (Aubert, 2011).

The Dialogic Literary Circle, also known as "Seminars with the book in hand", are developed from the reading, commentary and sharing of a paragraph that is of interest or provokes some reflection among the participants, exposing their interpretations to study the text in depth according to their life experiences (Racionero \& Brown, 2012). To do this, a series of fundamental principles must be established as a reference framework, these being (Aubert et al., 2011; Flecha, 2014):

- Equal dialogue among all, for the construction of knowledge and learning.

- Consideration of cultural intelligence, understood as the universal capacity of learning for all people.

- Transformation of the interactions between equals from the creation of learning communities.

- Instrumental dimension of education that prioritizes the learning of areas whose mastery is transcendental for the learning of new ones.

- Solidarity, understood as a fundamental value based on mutual help to achieve learning for all.

- Equality of differences, supported by diversity and heterogeneity for the enrichment and expansion of learning.

- Creation of meaning, as a way to awaken interest and the usefulness of knowledge. 
In this way, the Dialogic Literary Circles are a method for students with different abilities, interests, expectations, etc. can share ideas from a reading of texts (Díaz \& Puyalto, 2017). As established by Flecha (2014), in this type of meeting the discussions are resolved on the basis of arguments, and there is a need to reach a consensus among the members of the group. This implies the transformation of the concept on which the teaching and learning process is based, as well as the role assigned to the main agents involved in it (Duran, 2017; Weyand et al., 2018).

According to Rekalde, et al. (2014), the dialogical gatherings aim to connect the academic world and reality, creating different learning spaces. These didactic tools make possible a more equitable teaching process, based on the principles of social justice and the elimination of hierarchies (Land, 2018). In addition, student participation in the teaching-learning process is encouraged, adopting new roles and establishing different relationships with the teachers involved (Jensen \& Bennet, 2016). In turn, it allows for the definition of new spaces of interaction, with a markedly open character (Cohrssen, et al., 2016; Marsh, et al., 2016; Radesjo, 2018), as well as the development of a research attitude among students (Hosein \& Rao, 2017). In short, it is a proposal that guarantees improved academic results and equality for the coexistence of its participants (Adams, et al., 2014; Malagón \& González, 2018).

For the student of Education, the Dialogic Literary Circles promote a process of deep reflection on a comprehensive and critical vision of education (Fernández, et al., 2012). In addition, it encourages student participation in the teaching-learning process, so that they can verbally express their emotions and what causes the reading of the selected texts; behind is the academic vision of the study of texts, relating the reading with their life experience (Esteban \& Izuzquiza, 2020). In this way, and according to Aguilar (2017), the future teacher must receive a democratic critical formation, since the reading of the word allows for the analysis of the reality in which each person develops, questioning the knowledge received during the process of academic formation.

In Spain, some experiences in the implementation of the Dialogic Literary Circles as a strategy for the improvement of the initial teacher training stand out. Chocarro (2013) proposes an experience of teaching innovation developed around the dialogical discussion groups, understood as a didactic resource for the initial training of teachers. This author proposes eliminating the barriers and strengthening more ties for the development of experiences similar to those developed by teachers for their professional future. For their part, Gabaldón, et al. (2016) propose this methodology for students of the Degree in Early Childhood Education, Primary Education and Sociology at the University of Valencia. The results show the high satisfaction of the students towards these experiences. Finally, Aguilar (2017) proposes the development of Dialogic Literary Circles in the Practicum for initial teacher training. This is a successful educational action linked to dialogical learning, so that the interactions that take place favour reflective learning based on a critical analysis of reality.

Therefore, as postulated by Mingorance et al. (2019) it is of interest to examine the variables that influence student performance in Higher Education, as well as the personal, social and institutional factors that have an impact on teaching-learning. In 
addition, it is necessary to investigate the character, as well as the procedures and effects of the dialogical methodological process in Higher Education (Laorden \& Foncillas, 2019). In this way, teacher evaluation allows for the provision of information to the university to improve the quality of education, while allowing teachers to improve their teaching process (Baek \& Cho, 2015).

\section{METHOD}

The work presented is based on a phenomenological perspective; specifically we focus on the hermeneutic or interpretative approach. According to Van Manen (2003), it aims to understand the meaning that people give to their lived experience. That is, to get to know the process of interpretation by which individuals define their world and act accordingly.

\section{Purpose and Objectives of the Investigation}

The purpose of this study is: analyze the experience of the students of the first year of the Degree in Early Childhood Education on the methodology of the Dialogic Literary Circles.

The objectives guiding the research are as follows:

- To acknowledge the perceptions and considerations that students have after their participation in the Dialogic Literary Circles.

- To find out the incidence of the Dialogic Literary Circles in the initial training of teachers and the need to apply it in their future professional practice.

\section{Description of Experience}

The field work has been developed in the subject "General Didactics in Early Childhood Education"; it is a first year subject included in the curriculum of the Degree in Early Childhood Education of the University of Jaen. For this experience, the teaching and research team has proposed the use of the methodology of the Dialogic Literary Circle for the development of one of the practical activities. This activity intends to bring the student closer to the analysis of the teaching role in the current educational system.

Prior to the implementation of the experience, there was an introductory session in which the students were explained the history and characteristics of this methodology. In order to facilitate their understanding, they were shown some videos with practical examples of the development of the same at different educational levels.

Afterwards, the students were given the different texts that were going to be worked on during the first term (time in which this practice was carried out). The texts were intentionally selected among all the students based on a proposal made by the teacher. The aim was to initiate them in the reading of academic texts that deal with the figure of the teacher in the present and the educational act.

For the development of the experience, the teaching team organized a work chronogram for all the students, creating work groups of between 20-30 students. Each of these 
groups carried out a total of 5 work sessions, working each day on one of the texts selected according to the procedure proposed by CONFAPEA (2012) in the Manual of Dialogical Literary Circles:

1. Everyone reads at home the text to be worked on in class that day.

2. They indicate which paragraph or paragraphs they found most interesting.

3. During the session, asking for their turn to speak, the students read aloud the text selected, commenting and explaining to their classmates what they have suggested.

4. The teacher opens the floor for everyone to critically comment on the paragraph(s) read by the student.

5. When they have finished all the opinions on that paragraph, the teacher gives the floor to another person and starts the cycle again.

6. The procedure continues in this way until the text is finished.

7. Before the beginning of each session, the teaching team tried to arrange the classroom in a semicircle, since this is the most recommendable way to carry out the sessions, within the possibilities offered by the fixed furniture of the class.

\section{Participants}

The context of the research corresponds to the University of Jaén, specifically, the first course of the Degree in Early Childhood Education. The subjects that participated in the research were all those who were enrolled in the subject of "General Didactics in Childhood Education". All of them were invited to participate, being a total of 230 students. The selection was determined by a series of criteria such as: the motivation of the student during the sessions in the dialogic meetings, the disposition to participate in the investigation, the interest towards the subject, the capacity for communication of the student, his previous experience in the accomplishment of dialogic meetings and other higher studies linked to the scope of the Education. In addition, the design took into account the heterogeneity of the groups, including as far as possible a gender balance, as well as students with special educational needs (dyslexia, visual disabilities). Finally, the research team had 90 students to form the discussion groups.

The choice of research subjects was based on intentional selection. In order to obtain the maximum information regarding the subject of study and thus be able to generate knowledge from an inductive perspective (Bisquerra, 2009). It has been combined with the understandable sample, since we are interested in selecting those subjects that are more specific by establishing criteria (McMilla \& Schumacher, 2012).

\section{Data Collection and Analysis Procedure}

To obtain the data, 9 discussion groups were formed, each with 10 students. To do this, follow the recommendations of authors such as Barbour (2014) as he considers that the 
ideal number to be able to effectively control all the speeches of its members is between 8 and 10 people. The research was carried out during the first four-month period of the 2019-2020 academic year.

A script was designed to direct the groups' discourse and to deepen the fundamental themes of the study. The following open questions were written: What do you think your participation in the discussion groups has been useful for? How have you felt in the Dialogic Literary Circles? Have you learned anything in the Dialogic Literary Circles? What advantages do the discussion groups have for your learning? Do you find any limitation in the discussion groups for your learning? Do you propose some improvements for the realization of this activity? Would you use the discussion groups in your professional practice as a future teacher? All of them focused on the objectives of the research.

The sessions lasted around 90 and 120 minutes, and were recorded to collect all the information obtained and to be able to transcribe it later. Previously, the participants were informed of the purpose of the research, we guaranteed their anonymity and obtained their authorization to make the recording.

Afterwards, the data was analyzed through content analysis, with the aim of discovering the meanings of the data collected (Tójar, 2006). To do this,followed the phases established by Krippendorff (2002):

1. Formulation of the data. This first phase consists of the first reading of all the data obtained. It is intended to try to know the material, reading it several times carefully and organizing it to determine the units of meaning and to record the information.

2. Reduction of the data. At this point, the different categories and subcategories are established (see table 1). By selecting the categorization process in a mixed way, that is, categories have already been created based on the script used for the discussion groups and the research objectives. But categories have also been established that have been born from the data collected itself.

3. Inference and analysis. In this third phase, once the material to be worked on has been organised, inferences are made and the most relevant and significant results obtained are analysed. The program Nvivo 12 has been used for this purpose, since it facilitates and enriches our work through the word clouds. 
Table 1

List of categories, description and instrument questions

\begin{tabular}{lll}
\hline Categories & Description & Questions \\
\hline Potentialities & $\begin{array}{l}\text { What is the purpose of participation } \\
\text { in the Dialogic Literary Circles in the } \\
\text { initial teacher training }\end{array}$ & $\begin{array}{l}\text { What do you think your } \\
\text { participation in the discussion } \\
\text { groups has been useful for? }\end{array}$ \\
\hline Learning & $\begin{array}{l}\text { Knowledge and skills acquired by the } \\
\text { student during the Dialogic Literary } \\
\text { Circles }\end{array}$ & $\begin{array}{l}\text { Have you learned anything in the } \\
\text { Dialogic Literary Circles? }\end{array}$ \\
\hline Perceptions & $\begin{array}{l}\text { Evaluation of the student of the } \\
\text { methodology used in the Dialogic } \\
\text { Literary Circles }\end{array}$ & $\begin{array}{l}\text { How have you felt in the Dialogic } \\
\text { Literary Circles? }\end{array}$ \\
\hline Disadvantages & $\begin{array}{l}\text { Disadvantages or limitations of this } \\
\text { methodology for student learning }\end{array}$ & $\begin{array}{l}\text { What advantages do the discussion } \\
\text { groups have for your learning? } \\
\text { Do you find any limitation in the } \\
\text { discussion groups for your learning? }\end{array}$ \\
& $\begin{array}{l}\text { Do you propose some improvements } \\
\text { for the realization of this activity? }\end{array}$ \\
\hline Improvements & $\begin{array}{l}\text { Proposals to improve this } \\
\text { methodology in Higher Education }\end{array}$ & $\begin{array}{l}\text { Would you use the discussion } \\
\text { groups in your professional practice }\end{array}$ \\
\hline $\begin{array}{l}\text { Practical } \\
\text { professional } \\
\text { use }\end{array}$ & $\begin{array}{l}\text { Considerations regarding the } \\
\text { implementation of the methodology } \\
\text { of the Dialogic LIterary Circles in } \\
\text { your future professional practice }\end{array}$ & \begin{tabular}{l} 
as a fure teacher? \\
\hline
\end{tabular}
\end{tabular}

\section{FINDINGS}

The results are presented meeting the objectives that guide this research, closely linked to the categories used to make the inferences (see table 2).

Table 2

Presentation of results in relation to objectives

\begin{tabular}{lll}
\hline Objectives & Categories & $\begin{array}{l}\text { Number of } \\
\text { frequencies }\end{array}$ \\
\hline To know the perceptions and considerations that & Potentialities & 76 \\
\cline { 2 - 3 } $\begin{array}{l}\text { students have after their participation in the Dialogic } \\
\text { Literary Circles. }\end{array}$ & Perceptions & 86 \\
\cline { 2 - 3 } $\begin{array}{l}\text { To find out the incidence of the Dialogic Literary Circles } \\
\text { in the initial training of teachers and the need to apply it } \\
\text { in their future professional practice. }\end{array}$ & Learning & 42 \\
\cline { 2 - 3 } & Disadvantages & 73 \\
\cline { 2 - 3 } & $\begin{array}{l}\text { Practical } \\
\text { professional use }\end{array}$ & 88 \\
\hline
\end{tabular}

However, it is very interesting to start by showing a content analysis by performing a word frequency search of the information collected. The procedure has been as follows, the 500 most frequent words have been selected and the option of grouping exact matches has been chosen. Once this has been done, the empty words have been eliminated, previously consulting their content and selecting the most relevant ones. Thus, with a word cloud mark, the most relevant words of the research are shown in a very graphic way (see image 1). The central and largest words are those most treated by 
the subjects of the research and the smaller ones are those with a lower number of frequencies.

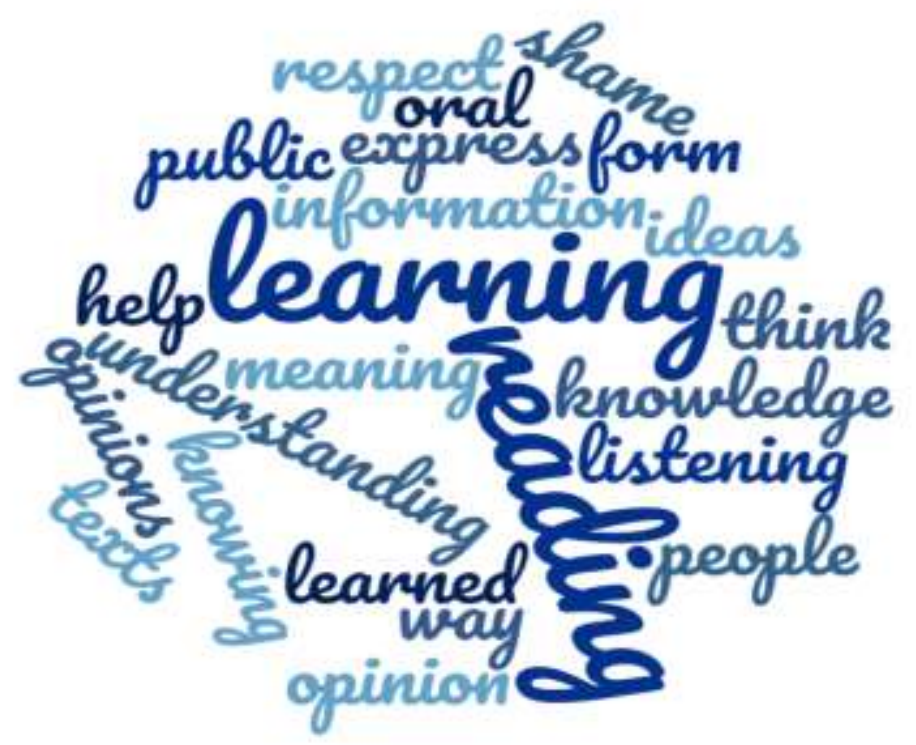

Image 1

Word cloud mark

Based on the most frequent and biggest words in the cloud brand like "learning" and "reading". It can be seen that in the TDP they have learned different topics around the field of education, through reading but also through active listening and opinion of other colleagues' opinions. This is corroborated by the results obtained with the different textual quotations.

Secondly, we can see the smaller words, some of them like "public", "shame", "express", "oral" and "express". They are really important in this research because the students had a process of adaptation to this methodology, and they were shy to speak in public and in front of their classmates. So, this has helped them to develop communication and expression skills.

\section{Analysis of potentialities and perceptions about Dialogic Literary Circles according to their protagonists}

Students consider that the implementation of the Dialogic Literary Circles in the subject of "General Didactics in Early Childhood Education" has allowed them to get to know in first person a new methodology that, in its majority, they did not know. By using it in the different sessions, it has led them, first of all, to encourage reading about didactic and pedagogical topics related to their initial training. By promoting the reading and 
comprehension of the texts, the students point out that it has led them to broaden and enrich their vocabulary, as well as to improve their reading comprehension.

In addition, the implementation of the Dialogic Literary Circles are very interesting. They lead to first-year students, who are still reluctant to actively participate in the classroom, becoming involved and protagonists of their own learning. In order to do so, they have to give their opinion about the part of the text read and explain it to the rest of their classmates. This promotes their need to communicate correctly so that everyone understands them and to adequately express what they have understood and learned from the text. Therefore, there is an impulse in the student to improve and develop communication and expression skills. This is shown in the following quotes:

"To better develop my oral expression, while learning many key words and vocabulary which has made it less repetitive with the same words or expressions when exposing something" (Ref. 73).

The Dialogic Literary Circles have also been useful for the students to integrate themselves into the class group. As it is their first year at the university, they are somewhat out of place, which helps the companionship and the establishment of friendship among equals. It also makes this task easier for those who are more shy and withdrawn. As reflected in these references:

"It has helped me to know more about the topics covered in the texts and has helped me to be able to speak in public since I am quite shy" (Ref. 74).

Losing, at the same time, that fear of speaking in public, since they do not usually do it at school and are not used to it: "To lose the fear of speaking in public and letting go more with my classmates" (Ref. 44).

Dialogic Literary Circles help to create a group feeling and to respect all colleagues, regardless of their personal or social characteristics. This also encourages respect for the opinions of others. This is one of the main reasons for them to feel free to express their point of view about the understanding of the texts:

"First of all, because by encouraging this reading, dialogue and listening on the subject to be discussed, it is a very good way of learning in a more practical way about what is being exposed. And secondly because it helps to communicate with others, to give your point of view and to get out of your comfort zone by facing a discussion group. $100 \%$ learning". (Ref. 52)

Without forgetting how important it is to comply with the rules governing the conduct of the talks, such as respect for the speaking time, as shown in the following reference: "To improve communication and respect more the speaking time" (Ref. 5).

They think that this way of working in class helps them to learn by themselves but also to learn from others: "So that other people can listen to my opinion and thus learn as I do from them" (Ref. 9). 
Therefore, it is an appropriate methodology to keep the students' attention by the dynamics of participation and attention to the opinions of the classmates: "They help us not to be distracted in class since it is a very dynamic method" (Ref.2).

Focusing on the students' perceptions of the Dialogic Literary Circles, most indicate that they have felt comfortable with this methodology, which has allowed it to create a good working environment, as these students point out:

"Well, since I haven't worked with this method before and I consider it a very good way to deal with topics you know by listening to different versions of what you think and topics you don't know to learn new things and try to reflect." (Ref. 17)

They also express that it is a more dynamic and attractive method of learning: "It is a dynamic way of learning and more attractive, this way the classes become more enjoyable". (Ref. 16)

Those who have a more negative opinion of the methodology, mainly because of that shyness to participate and speak in public that most of them have: "A disadvantage may be the shyness of the participants, since they may not speak out of shame" (Ref. 12)

This experience of participation in the talks leads them to propose some improvements. Among them, they highlight the importance of the talks being done in a continuous way in the different subjects, due to all the advantages they imply for the learning process:

"Personally, I really liked this proposal of the talks. There is always something to improve in everything and of this, it would be better to have more time and do it in the second term" (Ref. 31)

They also consider that the texts should be proposed by them so that everyone will have a great added interest, and thus not feel inhibited to participate actively: "Activities in which we can talk about topics chosen by us to free ourselves more" (Ref. 2).

The shame is repeated during the development of the talks, so it is proposed to involve more those students who do not dare to intervene:

"I propose that more emphasis be placed on those who do not participate so that they can open up and reach a point where they can express themselves without shyness. In other words, ask these people questions so that they can participate." (Ref. 33)

Finally, and to complete what they have learned in the discussions, the students think that it would be interesting to make a portfolio or simply a blog where they can express their opinions. This is reflected in this reference: "That apart from debating we can also write after each session what we have thought of the discussion" (Ref. 35).

\section{Student's experience before the Dialogic Literary Circles and its implementation in the future professional practice}

Students have seen the potential of this methodology to be applied in the Early Childhood Education classroom. It is essential that knowledge is learned, but also values and attitudes. This must be done in a good working environment, where students feel 
free to express their opinions and respect those of their peers. In this way, quality learning is achieved that allows for effective development in today's society:

"I have learned how important it is for children to develop in a friendly atmosphere and to express themselves openly and freely, so that they not only acquire knowledge but also learn to respect, to face up to speaking in front of others. These are very important qualities that they should learn from an early age so that they can be trained as adults in the future to function properly in society". (Ref. 1).

Students have had the opportunity to learn about the procedure for putting them into practice in class, with the participation of everyone, regardless of educational, social, cultural or economic level: "That you don't need to have a major education to participate in them" (Ref. 9).

In addition, they have learned the importance of listening to the opinions of others and what they can bring to you personally:

"I have learned that there are different opinions on current teaching issues, and that sometimes you can agree and sometimes not. It has also made me see several things that I thought were not so because of lack of information and knowledge" (Ref. 71).

They emphasize that in each of the talks they have learned different topics related to didactics and pedagogy. In this way, it has helped them to understand themes that are usually more abstract for them:

"Yes, from all the talks I have learned something that I did not know or I have increased my knowledge, besides they have changed my concepts that I thought were one way and it did not turn out that way" (Ref. 45).

As for the disadvantages, students consider this methodology to be very distant from those used in educational centres throughout their academic life, and therefore find it difficult to adapt to it. This is what one student shows: "At first it seems strange because of the lack of use in previous years" (Ref. 21)

Another drawback to be highlighted is the time needed to develop this methodological strategy. Students think that the period of development of this practice should be extended, increasing the number of sessions established for the sharing of texts read. This is reflected in the following statement:

"From my point of view, there are hardly any drawbacks to sharing. However, one aspect to highlight is that in one hour there is not always time to squeeze the maximum of ideas, nor to have all the people participate" (Ref. 69)

Finally, regarding the use of this methodology in their future professional practice, students show very favorable perceptions, supporting the implementation of the talks in their future as teachers: "Yes, because it is an enriching method in many aspects, from the sharing of various points of view to respect and improvement of communication" (Ref. 44). 
In addition, it is an active methodology that favors student participation and research, being the protagonist of their learning: "Yes, since it favors the development of research by the students as well as the participation of all and to be able to know more about other things by investigating them more deeply" (Ref. 34).

Finally, students are committed to the continuous training and updating of teachers to improve the quality of education. With the application of the Dialogic Literary Circles one can learn in an integral way, acquiring knowledge and also other values. Therefore, it is a very interesting method for teaching in Early Childhood Education:

"As a future teacher, I know that I must always be training, learning and reinventing myself, even when you finish your degree and get a permanent job, so you are constantly thinking about the best learning methods for children to learn and have fun at the same time. And I think that the talks are a good method to achieve this, it has benefits beyond the reading itself" (Ref. 1).

\section{CONCLUSION AND DISCUSSION}

This research has allowed the implementation of an innovative experience based on the use of the Dialogic Literary Circles in Higher Education. This is an active methodology that students are often unaware of, excluding some who have practiced it in previous studies.

Generally, students have experience in the development of traditional methodologies, which places the teacher at the centre of the teaching event. This leads to the student's critical thinking not being promoted and their learning being more directed. However, the Dialogic Literary Circle give the student the opportunity to read and comment on texts that are usually complex and with unknown contents in a reflective, critical and shared way. And even so, they understand them, because they learn individually but also as a group. They are the ones who direct their own learning. This is what Flecha (2015) calls transformation, a way of learning through dialogue that leads to the ability to transform people's lives.

It can be considered that, in general, students in the Early Childhood Degree have had a very positive experience participating in this type of active methodology. At first, they were a little reluctant, until they got to know the dynamics and became deeply involved. They have acquired pedagogical and didactic knowledge, but at the same time, they have seen the importance of being part of a group, of respecting their turn to speak, of listening to the opinions of others and respecting them, learning from what their peers say and expanding their knowledge. These are the basic rules for holding discussion groups (Arrow, 2014).

Without forgetting the promotion of reading and the expansion of vocabulary that comes with the development of the discussion groups. They also promote critical thinking about the texts discussed, thus avoiding learning by heart. They also develop a research attitude (Hosein \& Rao, 2017).

It is a methodology where the central axis is the student, leaving the teacher as a mere guide of the didactic act. As Jensen \& Bennet (2016) point out, there are new roles and 
interactions between the teacher and the students. In general, they have learned to participate as students, but they have also learned how it works and the rules to apply it as future teachers. Without a doubt, most of them are in favour of putting this methodology into practice in their future professional activity, and the experience of seeing its benefits first-hand is positive.

This research has shown how universities can innovate and leave behind the development of traditional methodologies, promoting active and collaborative learning of the student and fostering a high motivation towards study and interest in complex pedagogical topics. The student is the protagonist of their own learning, with the teacher in second place. In this way, it is possible to train professionals with skills related to critical analysis, collaborative decision-making, systemic reflection and a sense of responsibility (Muga, 2015).

This way of teaching, also carried out by other researchers (Aguilar, 2017; Aubert, 2011; Fernández,et al., 2012; Laorden \& Foncillas, 2019; Segovia \& García, 2020) and at the European level by the Includ-ed project (Flecha, 2015), leads to the teaching of quality education for all, to offer an equitable and equal education, regardless of the personal characteristics of each student. Therefore, with this type of methodology it leads to the achievement of the objectives for sustainable development (United Nations General Assembly, 2015).

At the same time, the real involvement of all the students has been encouraged, although with the limitation of the furniture in the classroom and having very large groups. We are aware that if we had avoided such limitations, it would have been even more fruitful to hold the pedagogical dialogical meetings.

As future lines of research, we propose the implementation of this innovative experience among students assigned to Degrees in various branches of knowledge. This allows for the comparison of perceptions according to the initial training received by the student, while at the same time analysing the perspective of other agents involved in its application, such as the teaching staff.

\section{REFERENCES}

Adams, A., Brock, R., Gordon, K., Grohs, J. \& Kirk, G. (2014). Service, dialogue, and reflection as foundational elements in a living learning community. Journal of Student Affairs Research and Practice, 15(3), 179-188.

Aguilar, C. (2017). The Dialogic Literary Circle in the practicum of the formation initial of teachers. Revista Iberoamericana de Educación, 73(2), 9-22.

Aguilera. A., Mendoza, M., Racionero, S. \& Soler, M. (2010). The Role of the University in Learning Communities. Revista Interuniversitaria de Formación del Profesorado, 67(24), 45-56.

Aubert, A. (2011). Moving beyond social exclusion through dialogue. International Studies in Sociology of Education, 21(1), 63-75. https://doi.org/10.1080/09620214.2011.543854 
Baek, W., \& Cho, J. (2015). Challenging the Sustainability of an Education System of Evaluation and Labor Market Outcomes. Sustainability, 7(12), 16060-16075. https://doi.org/10.3390/su71215808

Barbour, R. (2014). The focus groups in qualitative research. Madrid: Ediciones Morata.

Chocarro, E. (2013). Dialogic gatherings, a didactic resource in teacher training. $\begin{array}{lllll}\text { Historia } & y & \text { Comunicación } & \text { Social, } & 18,\end{array}$ http://dx.doi.org/10.5209/rev_HICS.2013.v18.44238

Cohrssen, C., Niklas, F. \& Tayler, C. (2016). "Is that what we do?' Using a conversation-analytic approach to highlight the contribution of dialogic reading strategies to educator-child interactions during storybook reading in two early childhood settings. Journal of Early Childhood Literacy, 16(3), 361-382. https://doi.org/10.1177/1468798415592008

CONFAPEA. (2012). Manual of Dialogic Literary Gathering. Madrid: Ministerio de Cultura.

Díaz, M.P. \& Puyalto, C. (2017). The voice of people with intellectual disabilities in research: towards the development of inclusive research. Revista de Educación Inclusiva, 7(2), 84-97.

Duran, D. (2017). Learning-by-teaching. Evidence and implications as a pedagogical mechanism. Innovations in Education and Teaching International, 54(5), 476-484. https://doi.org/10.1080/14703297.2016.1156011

Esteban, R.M., \& Izuzquiza, D. (2020). As reuniões pedagógicas dialógicas na universidade como elemento de inclusão educacional. Revista Internacional De Formação De Professores, 5, 1-22.

Fernández, S., Garvín, R. \& González, V. (2012). Dialogical pedagogical discussions: With the book in hand. Revista Electrónica Interuniversitaria de Formación del Profesorado, 15(4), 113-118.

Flecha, R. (2014). Sharing words: adult learning through dialogue. Barcelona: Paidós.

Flecha, R. (2015). Successful educational actions for inclusión and social cohesion in Europe. Berlín: Springer.

Gabaldón D; Obiol, S; Beltran J. \& Benedito A. (2016). Dialogical gatherings in the teaching degree. Congreso In-Red 2016. Congreso Nacional de Innovación Educativa y De docencia en Red. Universitat Politécnica de València.

González, R., \& Medina, A. (2017). The Professional Development of Early Childhood Teachers. In Medina, A., De la Herrán, A., \& Domínguez, M. C. (coord.). New Perspectives on Teacher Training, pp. 23-58. Madrid: UNED. 
Hosein, A., \& Rao, N. (2017). Students' reflective essays as insights into student centred-pedagogies within the undergraduate research methods curriculum. Teaching in Higher Education, 22(1), 109-125. https://doi.org/10.1080/13562517.2016.1221804

Jensen, K. \& Bennett, L. (2016). Enhancing teaching and learning through dialogue: a student and staff partnership model. International Journal for Academic Development, 21(1), 41-53.

Krippendorff, K. (2002). Content analysis methodology. Theory and practice. Barcelona: Paidos.

Land, C. (2018). Examples of c/critical coaching: An analysis of conversation between cooperating and preservice teachers. Journal of Teacher Education, 59(5), 493-507. https://doi.org/10.1177/0022487118761347

Laorden, C., \& Foncillas, M. (2019). Dialogic gatherings and acquisition of competencies: the perception of social education students. Aula De Encuentro, 21(1): 40-59. https://doi.org/10.17561/ae.v21i1.3

Malagón, J. D. \& González, I. (2018). Impact assessment of the Dialogic Literary Gatherings in Learning Communities. Profesorado. Revista de Currículum y Formación de Profesorado, 22(4), 111-132. https://doi.org/10.30827/profesorado.v22i4.8400

Marsh, S., Waniganayake, M. \& De Nobile, J. (2016). Leading with intent: cultivating community conversation to create shared understanding. School Effectiveness and School Improvement, 27(4), 580-593. https://doi.org/10.1080/09243453.2015.1136337

Martín, R., López, C. \& Arguedas, R. (2020). Collaborative Learning Communities for Sustainable Employment through Visual Tools. Sustainability, 12, 2569. https://doi.org/10.3390/su12062569

McMillan, J. H. \& Schumacher, S. (2012). Educational investigation. A conceptual introduction. $5^{\mathrm{a}}$ ed. Madrid: Pearson Addison Wesley.

Mingorance, Á. C., Granda, J., Rojas, G. \& Alemany, I. (2019). Flipped Classroom to Improve University Student Centered Learning and Academic Performance. Social Sciences, 8, 315. https://doi.org/10.3390/socsci8110315

Muga, M. A. (2015). Competencies for sustainable development: capabilities, attitudes and values purpose of education in the framework of the post-2015 global agenda. Foro Educación, 13(19), 55-83.

Pérez-Gutiérrez, M., Salceda, M. \& Castañedo, JM. (2019). Curricular Dialogic Gatherings in the Degree in Early Childhood Education in the University of Cantabria. Infancia, Educación y Aprendizaje, 5(2), 286-292.

Racionero, S. \& Brown, M. (2012). Reading in more spaces and with more people. Cuadernos de Pedagogía, 429, 37-39. 
Radesjo, R. (2018). Learning and growing from 'communities of practice': autoethnographic narrative vignettes of an aspiring educational researcher's experience. Reflective Practice, 19(1), 68-80. https://doi.org/10.1080/14623943.2017.1361917

Rekalde, I., Alonso, J., Arandia, M., Martínez, I. \& Zarandona, E. (2014). Dialogical literary gatherings in university teaching processes: Reflections from teaching practice. Revista de Formación e Innovación Educativa Universitaria, 7(3), 155-172.

Segovia, B. \& García, M. M. (2020). The University in the School: Collaboration Project with the Network of Learning Community Centers. Revista de Innovación y Buenas Prácticas Docentes, 9(2), 24-36.

Soler, R., Mauri, M., Lafarga, P. \& Moreno, A. J. (2020). How to Teach Pre-Service Teachers to Make a Didactic Program? The Collaborative Learning Associated with Mobile Devices. Sustainability, 12(9), 3755. https://doi.org/10.3390/su12093755

Tójar, J. C. (2006). Qualitative research. Understand and current. Madrid: La Muralla.

United Nations General Assembly (2015). Transforming our world: the Agenda 2030 for Sustainable Development. Resolution approved by the General Assembly on September 25 ,

2015 https://unctad.org/meetings/es/SessionalDocuments/ares70d1_es.pdf

Vallet-Bellmunt, T., Rivera, P., Vallet-Bellmunt, I. \& Vallet-Belmunt, A. (2017). Cooperative learning, perceived learning and academic achievement in teaching Marketing. Educación XX1, 20(1), 277-297. https://doi.org/10.5944/educxx1.17512

Van Manen, M. (2003). Educational research and lived experience: human science for a pedagogy of action and sensitivity. Barcelona: Idea Books.

Weyand, L., Goff, B. \& Newell, G. (2018). The Social Construction of Warranting Evidence in Two Classrooms. Journal of Literacy Research, 50(1), 97-122. https://doi.org/10.1177/1086296X17751173

Zabalza, M. A. (2016). Being a college professor today. La cuestión universitaria, 5, 68-80. 